\title{
Cueva del Medio: A Paleoindian Site and Its Environmental Setting in Southern South America
}

\author{
Hugo G. Nami ${ }^{1}$, Calvin J. Heusser ${ }^{2}$ \\ ${ }^{1}$ Conicet-Igeba, Laboratory of Geophysics “Daniel A. Valencio”, Department of Geological Sciences, FCEN, UBA, \\ Ciudad Autónoma de Buenos Aires, Ciudad Autónoma de Buenos Aires, Argentina \\ Email: hgnami@fulbrightmail.org
}

Received 20 February 2015; accepted 3 April 2015; published 8 April 2015

Copyright (C) 2015 by authors and Scientific Research Publishing Inc.

This work is licensed under the Creative Commons Attribution International License (CC BY). http://creativecommons.org/licenses/by/4.0/

c) (i) Open Access

\begin{abstract}
This article reports the results of the palynological analysis obtained from one of the archaeological profiles exposed at Cueva del Medio, a Paleoindian site located at the southern tip of South America (Ultima Esperanza, Chile). The earliest occupation is located over a sand layer which follows the natural slope of the sedimentological matrix of the cave. The findings of this level are significant, as they demonstrate a clear Paleoindian context, linking humans with extinct fauna. Based on the palynological analysis and previous results obtained in the region, the environmental setting of Cueva del Medio is described. Paleoindian occupations of the cave, estimated to date from approximately 11 - 10 kya, may have taken place at about the time of initial, albeit ephemeral, Nothofagus expansion. Climate becoming more mesic was evidently transitory, and possibly favored some development of arboreal communities. Summer drought for a time afterward, in turn, was less favorable to the spread of trees, as inferred by the successive prevalence of steppe.
\end{abstract}

\section{Keywords}

Paleoindian, Palynology, Paleoenvironment, South America, Southern Cone, Chile

\section{Introduction}

During the late Pleistocene and early Holocene, at the time of glacier recession, the paleoecology in southern South America was characterized by fluctuating climates. Sea level was lower than today, and Isla Grande de Tierra del Fuego was joined to the continent (Rabassa \& Clapperton, 1990; McCulloch et al., 1997). The fossil

${ }^{2}$ Heusser passed away on 11 November 2006. R.I.P. 
record of Pleistocene fauna shows a broad faunistic diversity (Menegaz \& Nami 1994; Nami \& Menegaz, 1991). Together with the vegetation, the fauna was changing in the course of deglaciation and subject to strong volcanic activity (Stern, 1992). In this setting, the early hunter-gatherers developed adaptive strategies to cope with these changing landscapes.

Archaeological research in the region has shown much progress in revealing this past environment. Specifically, in the province of Ultima Esperanza (Magallanes, Chile), studies of archeology remain in a number of caves, and rock shelters have yielded excellent data. Among these sites, mention needs to be made of Cueva del Lago Sofía, Alero Dos Herraduras, Alero Pedro Cárdenas, and Cueva del Medio.

Cueva del Medio $\left(51^{\circ} 34^{\prime} 26^{\prime \prime} \mathrm{S} ; 72^{\circ} 35^{\prime} \mathrm{W}\right)$ yielded significant evidence for a better understanding of the postglacial landscape. In fact, in southern South America, evidence of early hunter-gatherers societies is very scarce. Between 1930s and 1950s, Dr. Junius Bird of the American Museum of Natural History (New York) reported discoveries at Fell and Pali Aike caves in southern Chile, approximately $150 \mathrm{~km}$ to the east of Ultima Esperanza. From these sites came the first reliable evidence of coexistence between Pleistocene fauna and human beings (Bird, 1938, 1946, 1988). Fifty years later, similar discoveries have been made in Cueva del Medio (Nami, 1985/1986, Figure 1).

Studies at Cueva del Medio, since the start of the project, have had an interdisciplinary perspective (see Nami 1987a). In order to have an approach to the natural environment in which the earliest inhabitants of the site lived, a palynological study was undertaken. Then, this article reports the results and interpretation of palynological analyze made on samples taken from one of the exposed profiles during the excavation of Cueva del Medio.

\section{The Sampling Site}

Cueva del Medio is about $90 \mathrm{~m}$ long, $40 \mathrm{~m}$ wide and $6 \mathrm{~m}$ high. It is formed in the Cerro Benitez (Figure 2a) conglomerate, consisting of rounded pebble, including many volcanics. It is located $\sim 1 \mathrm{~km}$ from the well-known
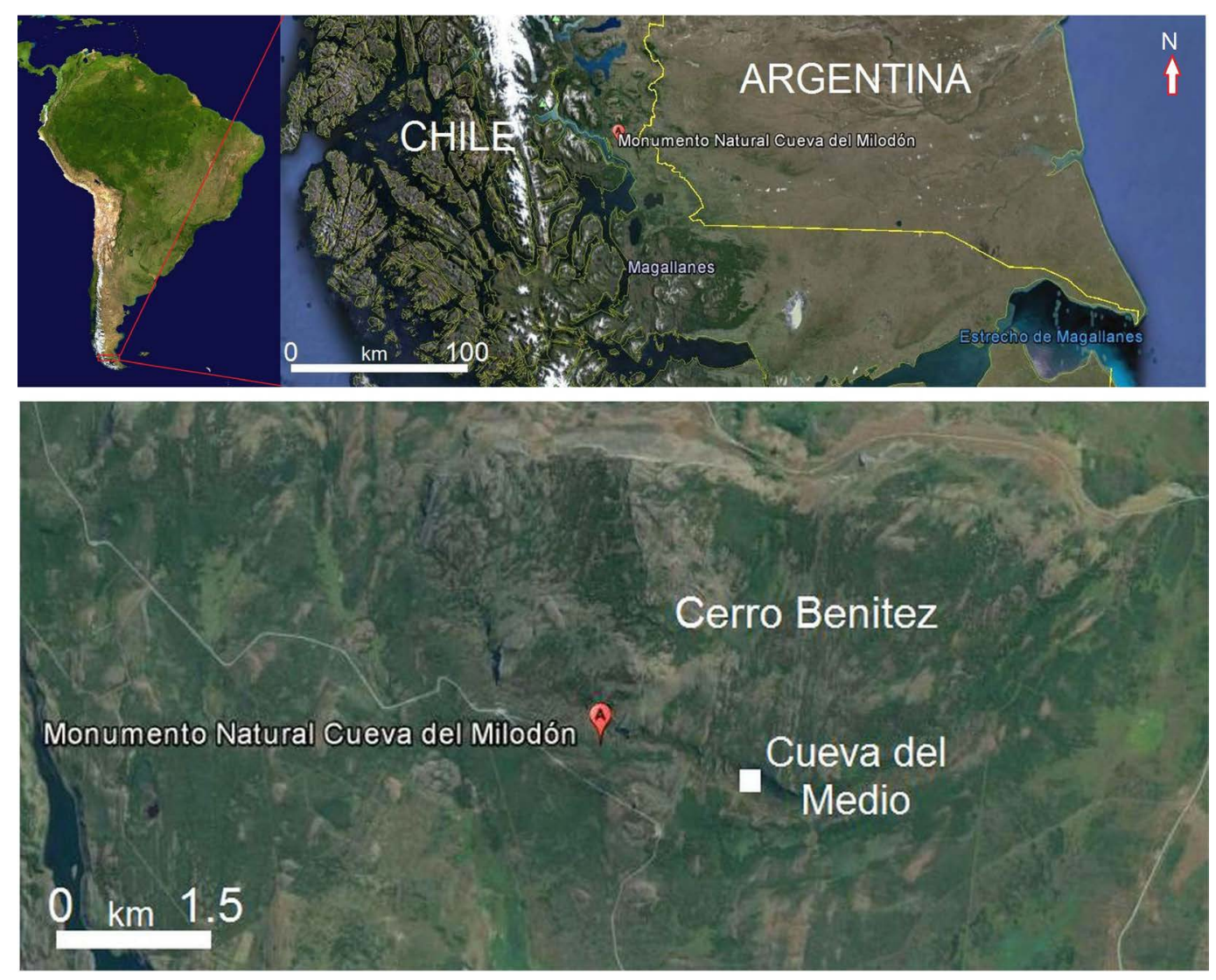

Figure 1. Map of South America showing the location of Argentina and Chile in the southern cone and $\mathrm{Cu}$ eva del Medio in the Cerro Benitez (after Google earth). 

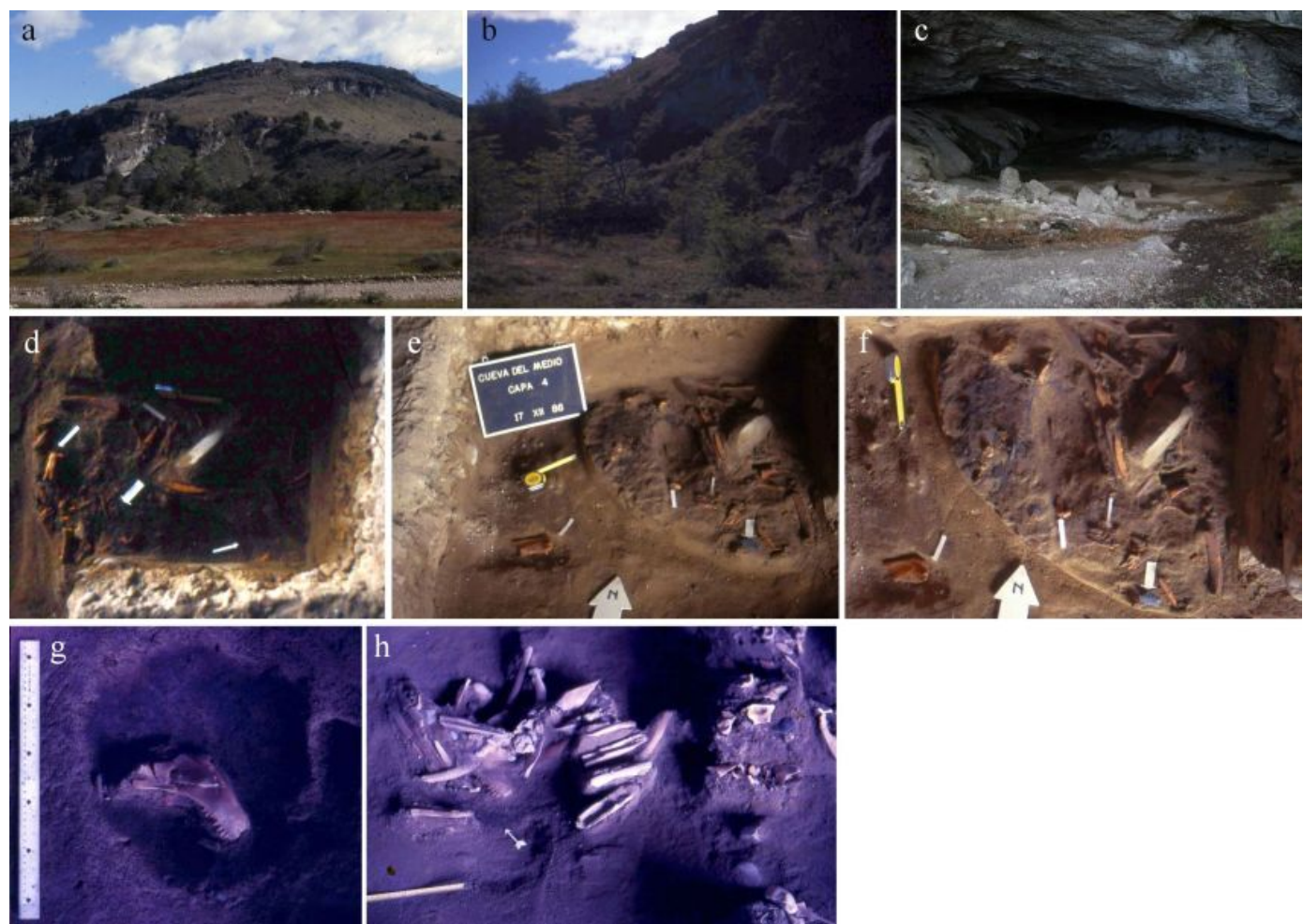

Figure 2. a General view of the Cerro Benitez; b Entrance of Cueva del Medio; c Inner part before the excavation; d-f Hearth found immediately below the pebbles level with Hippidion saldiasi bones associated to a fishtail projectile point; g-h Infant horse found the lower portion of the pile of bones covering a hearth (except when is clearly expressed all the photographs and drawings are by the author).

Mylodon Cave, a site which contained extensive Mylodon (sloth) and Hippidion (horse) remains (Sutcliffe 1986; Bird, 1988). The surface of Cueva del Medio has been defaced by pothunters. Ever since the discovery of Mylodon Cave in 1893 and the subsequent "Myldon rush" that attracted the attention to scientist from all around the world and scavengers alike. Their action destroyed a great portion of the sedimentary pile of Cueva del Medio. However, by fortune intact deposits have been found and, as seen below, in some places sealed by a layer of pebbles and cobbles deposited soon after the first human occupation of the cave. The screened sediments belonging from the pothunters' activity yielded numerous extinct and extinct fauna bones, lithic and bone tools.

During spring and summer 1986 and summers of 1987, 1989, 1992 and 1993 six archaeological expeditions were carried out. The site was divided into three zones for analytical purposes, the entrance, the interior and the back of the cave (Nami, 1989-1990). Approximately 80 square meters were excavated in the three zones. At that time, the main archaeological area was located in the inner part, but archaeological remains have also been found at the entrance and the back of the cave. Some results of this activity were given in different papers and reports (Allison, 1989; Hall, 1992; Nami, 1985/1986, 1987a, 1987b, 1989-1990, 1992, 1993, 1994, 1996, 1997, and others).

Stratigraphycally, four layers have been exposed. Layers 3 and 4 contain archaeological material. The archaeological record reveals a Paleoindian occupation spanning the Pleistocene-Holocene transition, also evidence of an early Holocene record. The Paleoindian level is located above a sandy layer which follows the natural slope of the sedimentological matrix of the cave. In the inner part of Cueva del Medio, most of the archaeological context was covered by a thick layer of pebbles and cobble, formed from the disaggregation of block which falls from the cave walls and ceiling. The findings demonstrate a clear Paleoindian context, linking humans with extinct fauna. These discoveries are also significant from the paleontological viewpoint. Consequently, after de discovery of Cueva del Mylodon, Cueva del Medio became an important source for paleontological data in Patagonia (Nami, 1987a, 1993; Nami \& Menegaz, 1991; Menegaz \& Nami, 1994; Nami et al., 1994). The Paleoindian level of Cueva del Medio yielded an unusual lithic assemblage consisting in several knives, lateral- and end-scrapers, and two diagnostic "fishtail" or Fell projectile points (Figure 2d-f and Figure 3a-b). Also fauna re 

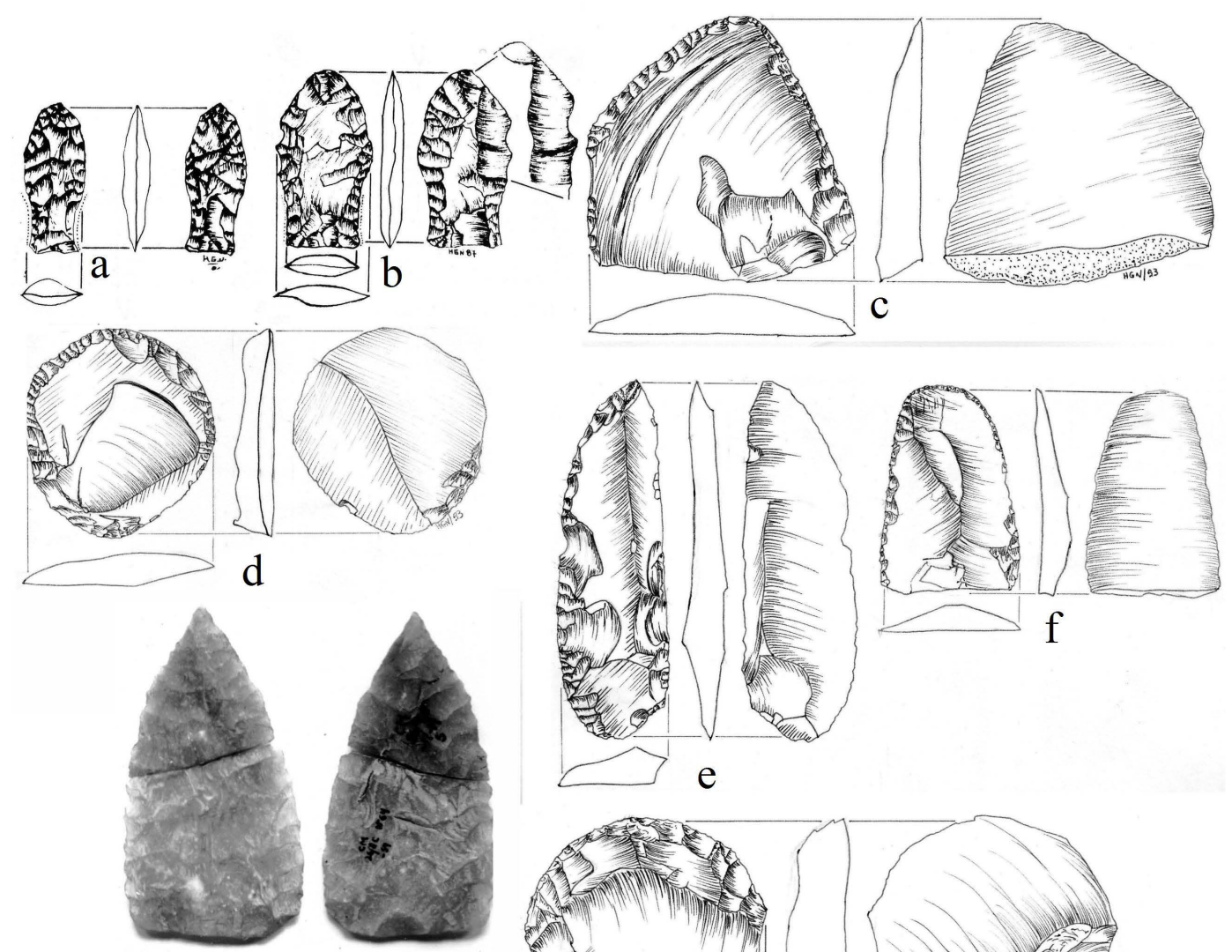

$\mathrm{g}$

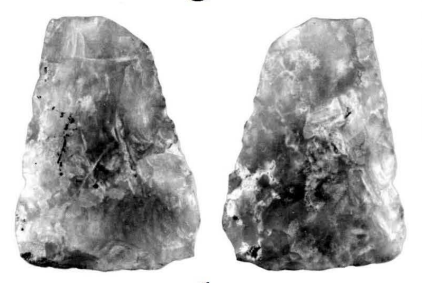

h

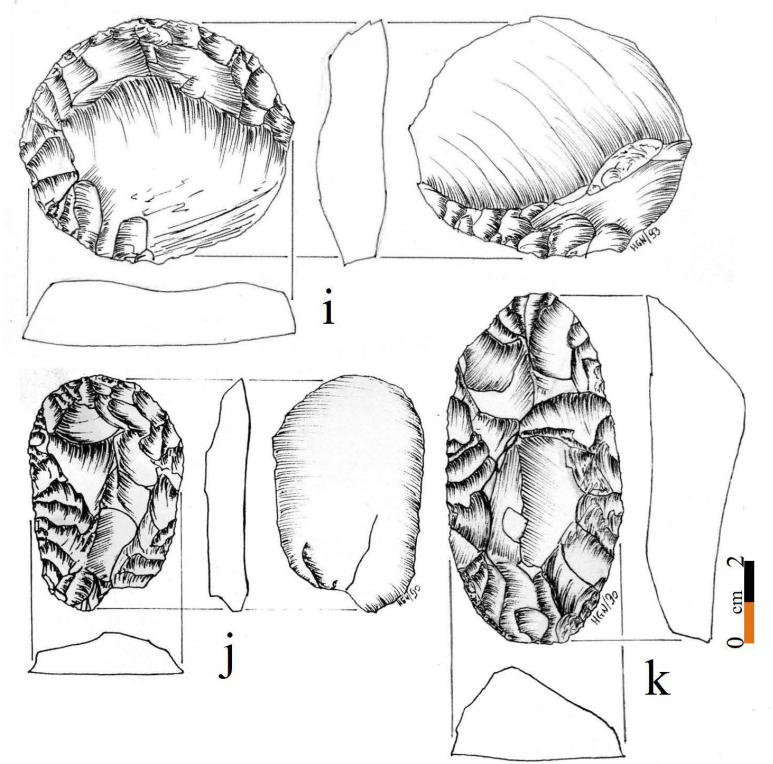

Figure 3. Lithic artifacts found in Cueva del Medio. From the Paleoindian level: a-b Fishtail points; c-f Diverse unifacial tools; g-i Early Holocene human occupations; g-h Stemless triangular projectile points; i Circular scraper; $\mathbf{j}$-k Probably Middle Holocene unifacial tools found on the back of the cave; $\mathbf{j}$ End-scraper; $\mathbf{k}$ Side-scraper.

mains, and a number of structures, artifacts, and ecofacts have been found. Remarkably, one of the hearths yielded charcoal, and calcinated horse (Hippidion saldiasi) bones in association with a "fishtail" point (Figures 2d-f). A second hearth contained a pile of bones, including a mandible of an infant horse, and various stone a bone tools (Figure 2g-h).

Worth to mention that evidence of Post-Paleoindian human occupations have been found in Cueva del Medio. A record of Holocene hunter-gatherers was only identified in a small portion of the excavation, and not covered by the level of pebbles and cobble. It mostly is a palimpsest (sensu Binford, 1981) with Paleoindian cultural remains and natural bones (Lyman, 1994), among them of Mylodon sp. (Nami, 1987a, Figure 4). Similar remains 

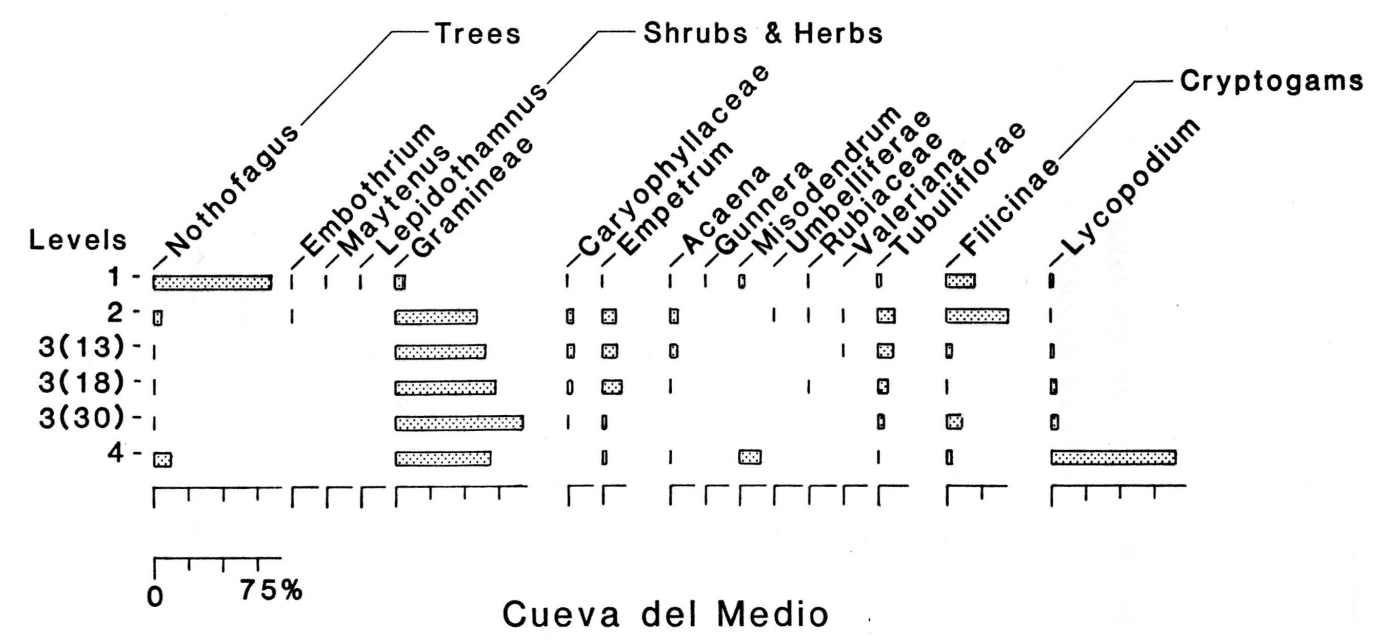

Figure 4. Pollen and spore diagram of six samples in a section from Cueva del Medio. Note: in sample 3, the numbers in parentheses indicate depths in $\mathrm{cm}$ below datum (illustration by C. Heusser).

in stratigraphy of this occupation have not been found in other stratigraphic portion of the cave, and consequently, its record is not replicable. Early Holocene hunter-gatherers vestiges enclose stemless triangular projectile points and other characteristic lithic artifacts have been recovered in level 3 and the surface of the site (Figures 3g-i). Similar assemblages were found in the Pali Aike, Fell (Bird, 1988) and Don Ariel cave in the Pali Aike area (Nami, 1995a, 1999a). In addition, in other places of Patagonia comparable assemblages with triangular projectile points have been found in association the extant Lama guanicoe. They were dated between $\sim 9.3$ and 6.0 kya (e.g. Gradin et al., 1984-1985; Nami, 1999a). Therefore, in Cueva del Medio lithic assemblages with stemless triangular points might be attributed to an occupation that inhabited the site during the early Holocene. A fact, that might occurred sometime between the aforementioned dates. Actually, in addition to the abovementioned diagnostic lithic artifacts, a radiocarbon essay obtained at the nearby site Pedro Cárdenas rock shelter yielded a date of $7415 \pm 165$ years bp witnessing the presence of early Holocene hunter-gatherers in the Cerro Benitez (Nami, 1989-1990). Being say that, as pointed before Cueva del Medio was affected by the relict hunters 'action. Because of this, have only survived the deposits sealed by the level of pebbles and cobble as well as the fallen roof blocks, and covered by the pile of sediments removed by the pothunters. Hence, the intact excavable portion related with the totality of the cave's surface was very limited. Consequently, is difficult to know with certainty, and therefore to reach reliable conclusions about the magnitude of the Holocene hunter-gatherers occupations in the site, which is evidenced by diagnostic lithic artefacts (Figures 3g-k), and two radiocarbon dates obtained in the back of the cave (Table 1).

\section{Dating Methods and Chronology}

Chronological studies include radiocarbon dating and palaeomagnetism (Barendrest, 1984; Parkes, 1986). Radiocarbon dates have been made in different laboratories using conventional and AMS methods. The results obtained in Cueva del Medio are given in Table 1 depicting the uncalibrated and calibrated ages using the "Calib radiocarbon calibration program" (Stuiver \& Reimer, 1993) and the calibration data set assembled by Reimer \& colleagues (2013). Paleomagnetic data show evidence of a geomagnetic excursion occurred in southern Patagonia during the Pleistocene-Holocene transition and Holocene (Nami, 1995b, 1999b; Nami et al., 1995). This fact suggests that the sediments recorded an anomalous geomagnetic field behaviour occurred during those times not only in other parts of Patagonia as well in South America (Moreiras et al., 2013; Nami, 2012, 2015).

\section{Pollen Record and Environmental Setting.}

\subsection{Samples, Materials and Methods of Analyses}

Samples $(n=6)$ of four stratigraphic levels from the floor of Cueva del Medio [1, 2, 3 (13), 3 (18), 3 (30), and 4] were collected for study of the fossil pollen and spore content of the cave deposits (square 24/5, east profile). 
Laboratory processing followed standard techniques (Faegri et al., 1989), employing nylon microscreens to concentrate pollen and spores in the size range of $10-150$ microns. Identifications of the fossils were made with reference to modern collections and literature (Heusser, 1971); frequencies (\%) of pollen are based on sums $=>300$ pollen/spores (Table 2 and Figure 4).

Table 1. List of AMS dates obtained in the sites described in this paper. The calibrated ages were calculated with the "Calib radiocarbon calibration program" (Stuiver \& Reimer, 1993) and the calibration data set assembled by Reimer \& colleagues (2013). ": From the same hearth; *: AMS date.

\begin{tabular}{|c|c|c|c|c|c|c|}
\hline $\begin{array}{l}\text { Portion of } \\
\text { the cave }\end{array}$ & Material dated & $\begin{array}{l}{ }^{14} \mathrm{C} \text { age } \\
\text { yr BP }\end{array}$ & $\begin{array}{c}95.4 \%(2 \sigma) \\
\text { cal age ranges } \\
(\text { cal yr BP) }\end{array}$ & $\begin{array}{c}\text { Relative area } \\
\text { under } \\
\text { distribution }\end{array}$ & Laboratory number & Reference \\
\hline Back & Charcoal & $2100 \pm 60$ & $\begin{array}{l}1904-1907 \\
1924-2184 \\
2198-2203 \\
2233-2305\end{array}$ & $\begin{array}{c}0.002 \\
0.9 \\
0.003 \\
0.11\end{array}$ & Beta-52521 & Nami, 1992 \\
\hline “ & “ & $4290 \pm 130$ & $\begin{array}{l}4524-5149 \\
5151-5289\end{array}$ & $\begin{array}{l}0.88 \\
0.11\end{array}$ & Beta-37167 & “ \\
\hline Inner & “ & $9595+115$ & $\begin{array}{l}10,595-10,624 \\
10,650-11,215\end{array}$ & $\begin{array}{l}0.02 \\
0.98\end{array}$ & PITT-0244 & Nami, 1987a \\
\hline “ & $\begin{array}{l}\text { Mammals } \\
\text { bone }\end{array}$ & $9770+70$ & $\begin{array}{l}10,809-10,844 \\
10,866-10,953 \\
11,070-11,329\end{array}$ & $\begin{array}{c}0.012 \\
0.074 \\
0.91\end{array}$ & Beta-40281 & “ \\
\hline “ & Charcoal & $10,310+70$ & $\begin{array}{l}11,825-11,908 \\
11,919-12,404\end{array}$ & $\begin{array}{l}0.07 \\
0.93\end{array}$ & Gr-N 14913 & “ \\
\hline “ & Burned bone & $10,350+130^{+}$ & $\begin{array}{l}11,647-11,666 \\
11,703-12,592\end{array}$ & $\begin{array}{c}0.005 \\
0.99\end{array}$ & Beta-58105 & “ \\
\hline Front & Charcoal & $10,430+80$ & $12,039-12,564$ & 1.0 & Beta-52522 & “ \\
\hline Inner & Bone & $10,430+100^{* \frac{1}{5}}$ & $11,988-12,619$ & 1.0 & NUTA-1734 & Nami \& Nakamura, 1995 \\
\hline “ & Burned bone & $10,550+120^{\ddagger}$ & $12,099-12,709$ & 1.0 & Gr-N 14911 & Nami, 1987a \\
\hline “ & Bone & $10,710+100^{*}$ & $\begin{array}{l}12,421-12,506 \\
12,511-12,767\end{array}$ & $\begin{array}{c}0.071 \\
0.93\end{array}$ & NUTA-1811 & Nami \& Nakamura, 1995 \\
\hline “ & “ & $10,860+160^{* \neq}$ & $\begin{array}{l}12,432-12,469 \\
12,523-13,084\end{array}$ & $\begin{array}{c}0.013 \\
0.99\end{array}$ & NUTA-2331 & “ \\
\hline “ & Charcoal & $10,930+230$ & $\begin{array}{l}12,240-12,273 \\
12,309-12,325 \\
12,380-13,330\end{array}$ & $\begin{array}{c}0.005 \\
0.002 \\
0.99\end{array}$ & Beta-39081 & Menegaz \& Nami, 1991 \\
\hline “ & Bone & $10,960+150^{*}$ & $13,639-13,114$ & 1.0 & NUTA-2330 & Nami \& Nakamura, 1995 \\
\hline “ & “ & $11,040+250^{* \ddagger}$ & $\begin{array}{l}12,430-12,472 \\
12,522-13,432\end{array}$ & $\begin{array}{c}0.009 \\
0.99\end{array}$ & NUTA-2197 & “ \\
\hline “ & “ & $11,120+130^{*}$ & $12,726-13,206$ & 1.0 & NUTA-1737 & “ \\
\hline
\end{tabular}

\subsection{Results}

A pollen and spore diagram (Figure 4) shows the dominance of Gramineae (grass) at depth and of Nothofagus (southern beech) in the topmost sample. These data imply the late arrival of threes at Cueva del Medio, especially Nothofagus but also Embothrium and Maytenus, following an episode of treeless grass steppe. Concomitant expansion of the Filicinae (ferns) is noteworthy in what appears to have been open woodland. Notophagus earlier at $12 \%$ in the basal sample may also have been proximal to the site, associated with the parasite Misodendrum and and with Lycopodium, which is often present in structurally open, arboreal communities. Intervening levels comprised mostly by Gramineae (as much 93\%), contain additional components, especially Caryophyllaceae, Empetrum, Acaena, and Tubuliforae (Compositae) characteristic of steppe (Pisano, 1977; Moore 1983).

The pollen record of levels samples at Cueva del Medio covers the late-glacial-Holocene transition, and interval subject to climatic and vegetation variability in southern Patagonia. The pollen also shows evidence of burning which has been attributed to Paleoindian activity (Heusser, 1987, 1993, 1994). Dr. M. E. Solari carried out andracological studies on the burned wood from Paleoindian hearths in the cave. The results of her research showed that hunter-gatherers, who lived in Cueva del Medio, burned Nothophagus pumilio and probably Empetrum (M. E. Solari, pers. comm., 1993). 
Table 2. Pollen analysis of four sample levels in a section of deposits from the floor of Cueva del Medio, Chile. Note: in level 3 , the numbers in parentheses indicate depths in $\mathrm{cm}$ below datum.

\begin{tabular}{|c|c|c|c|c|c|c|}
\hline \multicolumn{7}{|c|}{ Sample/level } \\
\hline Taxa $(\%)$ & 1 & 2 & $3(13)$ & $3(18)$ & $3(30)$ & 4 \\
\hline \multicolumn{7}{|l|}{ Trees } \\
\hline Nothofagus & 86 & 6 & + & + & + & 12 \\
\hline Embothrium & + & + & - & - & - & - \\
\hline Maytenus & + & - & - & - & - & - \\
\hline \multicolumn{7}{|l|}{ Shrubs and herbs } \\
\hline Lepidothamnus & + & - & - & - & - & - \\
\hline Gramineae & 6 & 59 & 66 & 73 & 93 & 69 \\
\hline Caryophyllaceae & + & 3 & 3 & 3 & + & - \\
\hline Empetrum & + & 10 & 11 & 14 & 2 & 2 \\
\hline Acaena & + & 5 & 5 & + & - & + \\
\hline Gunnera & + & - & - & - & - & - \\
\hline Misodendrum & 3 & - & - & - & - & 15 \\
\hline Umbelliferae & - & + & - & - & - & - \\
\hline Rubiaceae & + & + & - & - & - & - \\
\hline Valeriana & - & + & + & - & - & - \\
\hline Tubuliflorae & 2 & 13 & 11 & 7 & 4 & + \\
\hline \multicolumn{7}{|l|}{ Cryptogams } \\
\hline Filicinae & 21 & 44 & 3 & + & 11 & 3 \\
\hline Lycopodium & 2 & + & 2 & 4 & 5 & 91 \\
\hline
\end{tabular}

Paleoindian occupations of the cave, estimated to date from approximately $11-10 \mathrm{kya}$, is bracketed by samples 3 (30) and 4 and may have taken place at about the time of initial, albeit aphemeral, Nothofagus expansion. Climate becoming more mesic, was evidently transitory, and possible favored some development of arboreal communities. Summer drought for a time afterward, in turn, was less favorable to the spread of trees, as inferred by the successive prevalence of steppe.

This interpretation of the pollen data is conditioned by the depositional setting and character of the cave deposits, which are principally the results of wind and animal, including human transport. It is known that hunter-gatherers foraged or gathered plants at the time of flowering for food, fuel, and living style, and later brought them into the cave, where they were incorporated as waste by the cave inhabitants. From the palynological viewpoint, the process was no doubt selective, and contributes a measure of bias regarding the kinds, amounts, and occurrence of taxa found in the pollen record.

Within the limits of the chronology, the data conform in a general way with an overall shift from drier to more mesic conditions expressed by late-glacial-Holocene pollen data from other cave within kilometers of Cueva del Medio. At the renowned Cueva del Mylodon, expansion of Nothofagus at the expense of the steppe, inferring locally wetter conditions, in dated after $\sim 11.3$ and before 7.8 kya (Moore, 1978; Markgraf, 1985; Heusser et al., 1994), while at Cueva del Lago Sofía, it occurred after 11.5 kya (Prieto, 1991). At present, according to the vegetation mapping of Pisano (1981) the caves are located close to the boundaries of forest of deciduous southern beech (Nothofagus pumilio and N. antractica) and evergreen beech ( $N$. betuloides) and of steppe, which have undergone disturbance, particularly through settlement during the past century. 


\section{Final Remarks}

In summary, six samples taken at four stratigraphic levels in Cueva del Medio yielded data of the fossil pollen and spore content of the sampled deposit. This result is supported by other ones obtained in two neighboring sites in the area allowing adding new light on the environmental setting surrounding Cueva del Medio mainly during the Pleistocene-Holocene transition, particularly in a discrete time span of $\sim 11-10 \mathrm{kya}$, when the earliest hunter-gatherers that employ Fell projectile points have been living in the region.

\section{Acknowledgements}

We are deeply indebted to the Instituto de la Patagonia (University of Magallanes, Punta Arenas, Chile) for having sponsored the research at Cueva del Medio, and the University of Buenos Aires and CONICET for their continuous support; to the Bird Foundation, the Sigma Xi Scientific Research Society, the Wenner-Gren Foundation for Anthropological Research and the National Geographic Society for their financial support.

\section{References}

Allison, N. (1989). From the End of the Earth. Mammoth Trumpet, 5, 3-8.

Barendrest, R. W. (1984). Using Paleomagnetic Remanence and Magnetic Susceptibility Data for the Differentation, Relative Correlation and Absolute Dating of Quaternary Sediments. In W. C. Mahaney (Ed.), Quaternary Dating Methods (pp. 101-140). Amsterdan: Elsevier.

Binford, L. R. (1981). Bones. Ancient Man and Modern Miths. New York: Academic Press.

Bird, J. (1938). Before Magellan. Natural History, XLI, 16-28.

Bird, J. (1946). The Archaeology of Patagonia. In J.H. Steward (Ed.), Handbook of South American Indians 1 (pp. 17-24). Washington, DC: Smithsonian Institution Bureau of American Ethnology; Bulletin 143, Smithsonian Institution.

Bird, J. (1988). Travels and Archaeology in South Chile. In J. Hyslop (Ed.). Iowa City: Iowa University Press.

Faegri, K., Kaland, P. E., \& Krzywinski, K. (1989). Textbook of Pollen Analysis. New York: John Wiley and Sons.

Gradin, C. J., Alonso, F., Aschero, C. A., \& Aguerre, A. M. (1984-1985). Algunas Consideraciones sobre recientes dataciones radiocarbónicas para el Area Río Pinturas, provincial de Santa Cruz. Relaciones de la Sociedad Argentina de Antropología (N.S.), XVI, 275-283.

Hall, D. (1992). Paleoindias of Patagonia Used Pleistocene Animals. Mammoth Trumphet, 8, 1, 4.

Heusser, C. (1971). Pollen and Spores of Chile. Tucson: University of Arizona.

Heusser, C. (1987). Fire History in Fuego-Patagonia. Quaternary Research in South America and Antarctic Penninsula, 5, 187-221.

Heusser, C. (1993). Late-Glacial of Southern South America. Quaternary Science Reviews, 12, 345-350. http://dx.doi.org/10.1016/0277-3791(93)90042-K

Heusser, C. (1994). Paleoindians and Fire during the Late Quaternary in Southern South America. Revista Chilena de Historia Natural, 87, 435-443.

Heusser, C. J., Borrero, L. A., \& Lanata, J. L. (1994). Lateglacial Vegetation at Cueva del Mylodon. Anales del Instituto de la Patagonia, 21, 97-102.

Lyman, R. L. (1994). Vertebrate Taphonomy. Cambridge Manuals in Archaeology, Cambridge: Cambridge University Press. http://dx.doi.org/10.1017/CBO9781139878302

Markgraf, V. (1985). Late Pleistocene Faunal Extinction in Southern Patagonia. Science, 228, 1110-1112. http://dx.doi.org/10.1126/science.228.4703.1110

McCulloch, R., Clapperton, C., Rabassa, J., \& Currant, A. (1997). The Natural Setting. The Glacial and Post-Glacial Environmental History of Fuego-Patagonia. In C. Mc Ewan, L. Borrero, \& A. Prieto (Eds.), Patagonia: Natural History, Prehistory and Ethnography at the Uttermost End of the Earth (pp. 12-31). London: British Museum Press.

Menegaz, A., \& Nami, H. G. (1994). Late Pleistocene Faunal Diversity in Ultima Esperanza (Chile): Further Data from Cueva del Medio. Current Research in the Pleistocene, 11, 93-94.

Moore, D. (1978). Post-Glacial Vegetation in the South Patagonian Territory of the Giant Ground Sloth, Milodón. Botanical Journal of the Linnean Society, 77, 177-202. http://dx.doi.org/10.1111/j.1095-8339.1978.tb01398.x

Moore, D. (1983). Flora of Tierra del Fuego. Oswestry: Nelson.

Moreiras, S. M., Marsh, E., Nami, H., Estrella, D., \& Durán, V. (2013). Holocene Geomorphology, Tectonics, and Archaeology 
in Barrancas, Arid Central Andes Piedmont (33 S). Applied Geography, 42, 217-226.

http://dx.doi.org/10.1016/j.apgeog.2013.04.005

Nami H., \& Menegaz, A. (1991). Cueva del Medio: Aportes para el conocimiento de la diversidad faunística hacia el Pleistoceno-Holoceno en Patagonia Austral. Anales del Instituto de la Patagonia, 20, 117-132.

Nami, H. G. (1985/1986). Excavación arqueológica y hallazgo de una punta de proyectil "Fell I" en la Cueva del Medio, Seno de Ultima Esperanza, Chile. Informe preliminar. Anales del Instituto de la Patagonia, 16, 103-109.

Nami, H. G. (1987a). Cueva del Medio: Perspectivas arqueológicas para la Patagonia Austral. Anales del Instituto de la Patagonia, 17, 71-106.

Nami, H. G. (1987b). Cueva del Medio: A Significant Paleoindian Site in Southern South America. Current Research in the Pleistocene, 4, 157-158.

Nami, H. G. (1989-1990). Nuevos antecedentes sobre investigaciones arqueológicas en el area de Cerro Benítez (Ultima Esperanza, Magallanes). Anales del Instituto de la Patagonia, 19, 125-132.

Nami, H. G. (1992). Resumen de las actividades y nuevos datos obtenidos en la quinta campaña de investigaciones arqueológicas en Ultima Esperanza, Chile. Palimpsesto: Revista de Arqueologia, 2, 123-132.

Nami, H. G. (1993). Las excavaciones arqueológicas y los hallazgos de fauna extinta en el Seno de Ultima Esperanza, Chile. In J. L. Lanata (Ed.), Explotación de recursos faunísticos en sistemas adaptativos americanos (Vol. 4, pp. 123-133). Buenos Aires: Edición especial de Arqueología contemporánea.

Nami, H. G. (1994). Reseña sobre los avances de la arqueología finipleistocénica del extremo sur de Sudamérica. Chungara, 26, 145-163.

Nami, H. G. (1995a). Archaeological Research in the Agentinian Rio Chico Basin. Current Anthropology, 36, 661-664. http://dx.doi.org/10.1086/204413

Nami, H. G. (1995b). Holocene Geomagnetic Excursion at Mylodon Cave, Ultima Esperanza, Chile. Journal of Geomagnetism and Geoelectricity, 47, 1325-1332. http://dx.doi.org/10.5636/jgg.47.1325

Nami, H. G. (1996). New Assessments of Early Human Occupations in the Southern Cone. In T. Akazawa, \& E. J. E. Szathmáry (Eds.), Prehistoric Mongoloid Dispersals (pp. 254-269). Oxford: Oxford University Press.

Nami, H. G. (1997). Archaeology and Landscapes during the Pleistocene-Holocene Transition in the Southern Tip of South America. Paper presented at 62nd Annual Meeting, Nashville, TN: Society for American Archaeology.

Nami, H. G. (1999a). Arqueología de la localidad arqueológica de Pali Aike, Cuenca del río Chico (provincia de Santa Cruz, Argentina). I. Las investigaciones arqueológicas. Praehistoria, 3, 189-201.

Nami, H. G. (1999b). Possible Holocene Excursion of the Earth's Magnetic Field in Southern South America: New Records from Archaeological Sites in Argentina. Earth Planets Space, 51, 175-191. http://dx.doi.org/10.1186/BF03352222

Nami, H. G. (2012). New Detailed Holocene Paleomagnetic Records with Anomalous Geomagnetic Field Behaviour in Argentina. Geoacta, 37, 83-116.

Nami, H. G. (2015). New Paleomagnetic Results and Evidence for a Geomagnetic Field Excursion during the PleistoceneHolocene Transition at Pichincha Province, Ecuador. Geofisica Internacional, 54, 153-174.

Nami, H. G., Menegaz, A. N., \& Senatore, M. X. (1994). Alteraciones de los restos faunísticos óseos de Cueva del Medio: Un análisis preliminar. Actas y Memorias del XI Congreso Nacional de Arqueología Argentina. Resúmenes. Revista del Museo de Historia Natural de San Rafael, 13, 35-36.

Nami, H. G., Sinito, A. M., \& Gogorza, C. (1995). Primeros resultados de los estudios paleomagnéticos en sedimentos de Cueva del Medio (Ultima Esperanza, Chile). Anales del Instituto de la Patagonia, 23, 135-142.

Nami, H., \& Nakamura, T. (1995). Cronología radiocarbónica con AMS sobre muestras de huesos procedentes del sitio Cueva del Medio (Última Esperanza, Chile). Anales del Instituto de la Patagonia, 23, 125-133.

Parkes, P. A. (1986). Current Scientific Techniques in Archaeology. New York: St. Martin's Press.

Pisano, E. (1977). Fitogeografía de Fuego-Patagonia chilena. I. Comunidades vegetales entre las latitudes $52^{\circ}$ y $56^{\circ} \mathrm{S}$. Anales del Instituto de la Patagonia, 8, 121-250.

Pisano, E. (1981). Bosquejo fitogeográfico de Fuego-Patagonia. Anales del Instituto de la Patagonia, 12, 159-171.

Prieto, A. (1991). Cazadores tempranos y tardios en la Cueva del Lago Sofia. Anales del Instituto de la Patagonia, $20,75-99$.

Rabassa, J., \& Clapperton, C. (1990). Quaternary Glaciations of the Southern Andes. Quaternary Science Reviews, 9, 153174. http://dx.doi.org/10.1016/0277-3791(90)90016-4

Reimer, P. J., Bard, E., Bayliss, A., Beck, J. W., Blackwell, P. G., Ramsey, C. B., Buck, C. E., Cheng, H., Edwards, R. L., Friedrich, M., Grootes, P. M., Guilderson, T. P., Haflidason, H., Hajdas, I., Hatté, C., Heaton, T. J., Hoffmann, D. L., Hogg, A. G., Hughen, K. A., Kaiser, K. F., Kromer, B., Manning, S. W., Niu, M., Reimer, R. W., Richards, D. A., Scott, E. M., 
Southon, J. R., Staff, R. A., Turney, C. S. M., \& van der Plicht, J. (2013). IntCal13 and Marine13 Radiocarbon Age Calibration Curves 0 - 50,000 Years Cal Bp. Radiocarbon, 55, 1869-1887. http://dx.doi.org/10.2458/azu_js_rc.55.16947

Stern, C. (1992). Tefrocronología de Magallanes: Nuevos datos e implicaciones. Anales del Instituto de la Patagonia, 21, 129-141.

Stuiver, M., \& Reimer, P. J. (1993). Extended ${ }^{14} \mathrm{C}$ Data Base and Revised CALIB $3.0{ }^{14} \mathrm{C}$ Age Program. Radiocarbon, 35, 215-230.

Sutcliffe, A. J. (1986). On the Track of Ice Age Mammals. Cambridge: Harvard University Press. 